\title{
CLÉRIGOS DE ORIGEN CASTELLANO \\ COMO EMBAJADORES DE LOS REYES DE ARAGÓN ANTE EL REY JUAN II DE CASTILLA
}

\author{
CLERGYMEN OF CASTILIAN ORIGIN \\ AS AMBASSADORS OF THE MONARCHS OF ARAGON \\ TO THE CASTILIAN KING, JOHN II
}

\author{
MáXimo Diago HeRnANDo \\ Instituto de Historia, CSIC. Madrid
}

\begin{abstract}
Resumen: Breve semblanza de varios clérigos de origen castellano que estuvieron al servicio de los Trastamara de la Corona de Aragón durante la primera mitad del siglo XV, y sirvieron como embajadores de los monarcas aragoneses ante el rey Juan II de Castilla. Se da cuenta de algunas de las principales misiones que desempeñaron en la Corte castellana. Y se pone de manifiesto cómo los beneficios eclesiásticos fueron utilizados como medio de compensar a estos individuos por los servicios prestados a la Monarquía.
\end{abstract}

Palabras clave: Embajadores; Relaciones diplomáticas; Corona de Castilla; Corona de Aragón; Siglo XV.

\begin{abstract}
Brief characterization of several clergymen of Castilian origin that stayed at the service of the Trastamara dynasty in the Crown of Aragon during the first half of the fifteenth century, and served as ambassadors of the monarchs of Aragon to the Castilian king, John II. The author informs about some of the missions they carried out in the Castilian court. And he stresses the importance of using the ecclesiastical benefices as a way of compensating these individuals for their services to the Monarchy.
\end{abstract}

Keywords: Ambassadors; Diplomatic relations; Crown of Castile; Crown of Aragon; Fifteenth century.

\section{SUMARIO}

1. El contexto: Los intereses castellanos de los Trastamara de la Corona de Aragón.- 2. El arcediano de Niebla, clérigo y médico, en el desempeño de misiones diplomáticas en Castilla al servicio de los reyes de Aragón.- 3. Los hermanos Fernando y García Gómez de Riaza, clérigos de la capilla de la reina María.- 4. Maestro Francisco de Burgos: Un médico castellano al servicio de la reina de Aragón.- 5. Otros clérigos castellanos al servicio de la reina María.6. Conclusión. 


\section{EL CONTEXTO: \\ LOS INTERESES CASTELLANOS \\ DE LOS TRASTAMARA DE LA CORONA DE ARAGÓN}

Los contactos entre las Cortes castellana y aragonesa fueron frecuentes y estrechos durante todo el período bajomedieval y, como consecuencia, el intercambio de embajadores entre ambas Cortes alcanzó entonces un notable desarrollo. Tras la consolidación en el trono catalanoaragonés de un miembro de la familia real castellana, el infante Fernando de Antequera, como consecuencia de la muerte sin descendencia legítima del último representante de la casa de Barcelona, el rey Martín el Humano, dichos contactos se intensificaron aún más, dado que los miembros de la nueva familia real aragonesa siguieron teniendo importantes intereses, tanto políticos como económicos, en la Corona de Castilla, de donde eran originarios, y donde continuaron percibiendo rentas y ejerciendo jurisdicción en numerosos lugares de señorío. Y esta circunstancia favoreció sobre manera el frecuente intercambio de embajadores entre las dos Cortes.

Los embajadores fueron muchos y de procedencia muy variada, pero resulta fácil advertir que entre ellos alcanzaron una presencia muy notable, en términos relativos, los de origen castellano que formaban parte del estamento eclesiástico. Es un hecho bien conocido que los miembros del clero estuvieron habitualmente en el primer plano de la vida política en las sociedades europeas occidentales hasta el fin del Antiguo Régimen y el triunfo de las revoluciones liberales. Pero, aún así, sorprende constatar el gran número de clérigos que asumieron el desempeño de misiones diplomáticas por cuenta de los monarcas hispanos bajomedievales, y más en concreto de los Trastamara de la Corona de Aragón. El hecho de que los clérigos podían disponer de unas regulares fuentes de ingresos propias gracias a los beneficios eclesiásticos, probablemente favoreció el que estos monarcas, que se desenvolvieron en una situación financiera bastante precaria, y disponían de unos recursos de patronazgo muy limitados, los prefíriesen a los laicos para formar parte de su círculo de colaboradores más estrechos, pues les resultaba más fácil remunerarles y compensarles por los servicios prestados, mediante el simple expediente de iniciar las diligencias necesarias para tratar de conseguir que en Roma o en otras instancias se les proveyese de beneficios con los que se pudiesen mantener holgadamente.

Para profundizar en el conocimiento de este aspecto de la historia política hispana nos hemos propuesto en el presente trabajo llamar la atención sobre el lugar clave que en la diplomacia de los monarcas aragoneses del siglo XV ocuparon algunos clérigos de origen castellano, centrándonos en dar cuenta de algunos aspectos del perfil de unos pocos individuos pertenecientes a este estamento que estuvieron al servicio de Alfonso el Magnánimo, y su esposa la reina María, hermana del monarca castellano Juan II. Se trata de personajes que, aunque pertenecientes al estamento eclesiástico, dedicaron una 
parte importante de su actividad pública a tareas que en principio nada tenían que ver con su condición clerical. Dos de ellos, en concreto, el arcediano de Niebla y Francisco de Burgos, practicaron la medicina, y fueron sus conocimientos en esta materia los que en principio resultaron decisivos para que los Trastamara de la Corona de Aragón se mostrasen tan interesados por tenerlos a su servicio. Al analizar sus trayectorias podemos comprobar, por consiguiente, cómo en la época la pertenencia al estamento eclesiástico pudo representar para determinadas personas que se movían en entornos cortesanos una simple manera de asegurarse unos ingresos suficientes para en la práctica poder dedicarse a otras actividades distintas de las específicas de un clérigo. Es una más de las paradojas de un sistema social y político que, a diferencia del actual, establecía una diferenciación radical entre clérigos y laicos, al adscribirlos a dos jurisdicciones diferentes, pero que al mismo tiempo consideraba normal que los clérigos tuviesen una notoria participación en tareas de laicos, hasta el punto de abandonar del todo las propias de su estamento, o que los laicos se inmiscuyesen en asuntos de la regulación de prácticas religiosas que hoy consideramos de exclusiva incumbencia del clero.

\section{El ARCEDIANO DE NIEBLA, CLÉRIGO Y MÉDICO, EN EL DESEMPEÑO DE MISIONES DIPLOMÁTICAS EN CASTILLA AL SERVICIO DE LOS REYES DE ARAGÓN}

Entre todos los personajes de origen castellano que sirvieron a los Trastamara de Aragón en el desempeño de misiones diplomáticas en Castilla, ocupa un lugar preeminente la figura del arcediano de Niebla, Fernando Díaz de Toledo. Procedía este clérigo de una conocida familia de conversos toledanos que llegó a alcanzar notorio relieve político en la Castilla del siglo XV. Era primo del relator y secretario real Fernando Díaz de Toledo, individuo con notable influencia en la Corte del monarca castellano Juan II $^{1}$, en el que a su vez depositaron su confianza el monarca aragonés Alfonso el Magnánimo y su esposa, la reina María, y que se hizo célebre a raíz de dirigir en 1449 al obispo de Cuenca, Lope de Barrientos, una Instrucción en favor de la nación hebraica, oponiéndose a la primera tentativa que se dio en Castilla de establecer un estatuto de pureza de sangre.

Fernando Díaz de Toledo, arcediano de Niebla, además de participar muy activamente en la vida política de las Coronas de Castilla y Aragón, fue un reconocido profesional de la medicina, disciplina que probablemente comenzó a aprender en el monasterio jerónimo de Guadalupe, con el que

\footnotetext{
${ }^{1}$ Vid. Jean Pierre MolÉnAT, Campagnes et monts de Tolède du XIIe au XVe siècle, Madrid, 1997, pp. 569 y. 70. Propone este autor a la familia de los Alvarez de Toledo como un ejemplo de familia de origen judeoconverso que consiguió acceder al grupo aristocrático en el transcurso del siglo XV gracias al desempeño de funciones burocráticas y de la medicina en la Corte. Hermano del arcediano fue Juan Ramírez de Toledo, tesorero de Juan II, ya muerto en 1446. Primo del arcediano era también el contador Alfonso Alvarez de Toledo.
} 
mantuvo estrechos contactos a lo largo de su vida ${ }^{2}$. Frente a estas dos facetas de su actividad en las que tanto destacó, la política y la del estudio y práctica de la medicina, la de clérigo queda, por el contrario, bastante más oscurecida, hasta el punto de que hay motivos para sospechar que fue importante para su trayectoria sólo en la medida que le permitió obtener los ingresos necesarios para poder dedicarse con libertad a la política y a la medicina, gracias a que llegó a acumular varios beneficios en las iglesias de Castilla y Aragón, que le reportaron importantes ingresos, sin que en contrapartida haya constancia de que los sirviera en persona. Así, nos consta que además de arcediano de Niebla, en la catedral de Sevilla, fue canónigo en la catedral de Toledo, y arcediano de Alcira en la catedral de Valencia, y disfrutó de algunos otros beneficios menores en otras iglesias, sin que en ningún caso haya constancia de que residiese en alguna de ellas, al menos con cierta continuidad.

En una primera fase de su trayectoria cabe presumir que fue ante todo su condición de médico la que le abrió las puertas para su promoción en el entorno del infante Fernando de Antequera, regente del reino de Castilla por su sobrino el rey Juan II, y rey de Aragón a partir de 1412. En efecto, sabemos que comenzó a servir como médico a este poderoso personaje de la vida política peninsular cuando todavía era infante ${ }^{3}$, y continuó haciéndolo después de su acceso al trono aragonés, hasta el punto de que llegó a abandonar la cátedra de vísperas que ocupaba en la facultad de medicina de la universidad de Salamanca para poder dedicarse en exclusividad a atenderle ${ }^{4}$. Él se encontraba entre los médicos que le atendían en Perpiñán, cuando se vio afectado por el agravamiento de la enfermedad que terminó conduciéndole a la muerte.

Tras el fallecimiento de Fernando de Antequera, continuó al servicio de su viuda, Leonor de Alburquerque, y de sus hijos, manteniendo una relación particularmente estrecha con el primogénito, Alfonso el Magnánimo, rey de Aragón. No obstante, aunque no hay que descartar que éstos continuasen requiriendo sus servicios como médico, cada vez en mayor grado pasó a servirles en el desempeño de misiones propiamente políticas, que exigieron que a partir de entonces viviese a caballo entre las Coronas de Castilla y Aragón durante muchos años. Según Beltrán de Heredia, el arcediano de Niebla regresó a Castilla hacia el año 1421, a raíz de haber sido nombrado canciller y capellán de Leonor de Alburquerque, la viuda de Fernando de Antequera, la cual se había retirado a sus señoríos castellanos tras la muerte

\footnotetext{
${ }^{2}$ Vid. Nicholas G. Round, La correspondencia del arcediano de Niebla en el archivo del real monasterio de Santa María de Guadalupe, "Historia. Instituciones. Documentos", 7 (1980), pp. 215-268. Publica este autor una serie de cartas del arcediano, de su hermano Juan Ramírez y de varios familiares suyos, que se conservan en el monasterio de Guadalupe, y están fechadas entre 1420 y 1431 .

${ }^{3}$ Se le identifica como médico y familiar del infante Fernando de Antequera en una bula de Benedicto XIII, expedida en Peñíscola, 26-XI-1411. Vid. Vicente BELTRÁN DE HEREDIA, Bulario de la Universidad de Salamanca (1219-1549), 2 vols. Salamanca, Universidad, 1966. Doc. no 453. En aquel momento era todavía bachiller en medicina.

${ }^{4}$ Vid. Francisca VENDRELl de MILlÁs, Relación médica de la enfermedad del rey Fernando de Antequera, "Archivo Iberoamericano de Historia de la Medicina y Antropología Médica", $\mathrm{X}$ (1958), pp. 111-119.
} 
de su marido, abandonando para siempre la Corona de Aragón ${ }^{5}$. Y, es cierto que en varios documentos de la década de 1420 que edita este autor se le identifica como canciller y capellán de esta reina. Pero debieron ser cargos de carácter ante todo honorífico, que no exigían su permanencia en persona en el entorno de Doña Leonor, pues la documentación demuestra por el contrario que el arcediano no llegó a fijar su residencia donde ésta residía, sino que combinó estancias en la Corona de Aragón con otras en la Corte castellana, viajando con notable frecuencia de un reino al otro. Y la propia Doña Leonor llegó a quejarse porque, con ocasión de alguno de sus viajes a Castilla, no había encontrado tiempo siquiera para acudir a visitarla. Así ocurrió, por ejemplo, en 1420, cuando el arcediano se trasladó desde Aragón a la Corte castellana con la misión de cobrar el dinero de la dote de la reina María, esposa de Alfonso el Magnánimo. Durante este viaje, realizado por encargo del monarca aragonés, no acudió a entrevistarse con Doña Leonor, quien interpretó dicha omisión como un grave desaire, hasta el punto de que su hijo Alfonso se vio obligado, para serenar su ánimo, a dirigirle una carta, en la que le pidió que disculpase al arcediano, puesto que si no se había encontrado con ella había sido porque materialmente no le había resultado posible, pese a que lo había intentado, dando para ello incluso un rodeo de más de 20 leguas en su camino. Y además, en su descargo, le recordó que los negocios que éste tenía que tratar en la Corte castellana eran muy urgentes, puesto que debía procurar que se terminase de pagar el dinero que se debía de la dote prometida a su esposa ${ }^{6}$.

Alfonso el Magnánimo desde su acceso al trono aragonés proporcionó continuas muestras de favor hacia el que había sido médico personal de su padre, dando de este modo cumplimiento a las recomendaciones que le había transmitido este último en su lecho de muerte, donde le encareció que, tanto él como sus hermanos, procurasen favorecer en todo lo posible al arcediano de Niebla y a sus parientes, por los muchos servicios que les habían prestado ${ }^{7}$. Por ello le nombró "proveedor de los negocios de su Corte" y designó para puestos de responsabilidad a algunos de sus parientes, como, por ejemplo, su cuñado Gonzalo Gómez de la Cámara, a quien encargó en 1424 de la custodia de un prisionero de alto rango, Don Jaime, conde de Urgell, el candidato que había disputado el trono aragonés a Fernando de Antequera, tras el fallecimiento de su anterior guardián, Pedro Alfonso de Escalante ${ }^{8}$. Y no dudó en

\footnotetext{
${ }^{5}$ Vicente BELTRÁN DE HEREDiA, op. cit. vol. I, p. 153.

${ }^{6} \mathrm{ACA}$ (= Archivo de la Corona de Aragón, C (=Cancillería), reg. 2569, fol. 131, Alguer, 30-VIII-1420.

${ }^{7} \mathrm{~A}$ estas recomendaciones hace referencia expresa Alfonso $\mathrm{V}$ en varias cartas que envió a sus hermanos, los infantes Enrique y Juan, poco después de la muerte de su padre.

${ }^{8} \mathrm{ACA}, \mathrm{C}$, reg. 2678, fol. 123v, Zaragoza, 29-XII-1424. Carta de Alfonso V a su madre, la reina Leonor, solicitándole que ordenase que se hiciese entrega a Gonzalo Gómez de la Cámara de la fortaleza de Urueña, que le pertenecía a ella, aunque entonces estaba en poder de su hijo el infante Juan, para que allí fuese custodiado el prisionero. En dicha carta se hace constar también que éste estaba todavía en poder de la mujer y herederos de Pedro Alfonso de Escalante, quienes estaban demorando su entrega a Gonzalo Gômez de la Cámara. Sobre este mismo asunto había escrito Alfonso V pocos meses antes a Alfonso González de Guadalajara, secretario de su madre. Vid. reg. 2678, fol. 98, Barcelona, 8-IX-1424.
} 
interceder ante sus hermanos, los infantes Enrique y Juan, para que también ellos favoreciesen en todo cuanto pudiesen a los parientes del arcediano. Así en 1416 solicitó a Enrique que nombrase a Gonzalo Gómez, su cuñado, para el desempeño del oficio de guarda en su casa ${ }^{9}$, y poco después cursó una petición a Juan, para que concediese algún oficio honorable en su casa a su hermano Juan Ramírez de Toledo ${ }^{10}$, en favor del cual volvió a interceder de nuevo a comienzos de 1418 ante Enrique para que le nombrase como su contador mayor, en sustitución de Pedro García de Medina, quien acababa de fallecer ${ }^{11}$.

El afán que en todo momento mostró Alfonso el Magnánimo por favorecer al arcediano de Niebla se corresponde con la importancia de las misiones políticas y diplomáticas que le encomendó. Así, cabe destacar en primer lugar que fue él el designado para llevar a cabo la compleja tarea de negociar en la Corte castellana el cobro de las 200.000 doblas de oro que Juan II se había comprometido a entregar a su hermana María cuando ésta fue entregada en matrimonio a su primo Alfonso ${ }^{12}$. El arcediano comenzó a entender en este asunto ya en vida de Fernando de Antequera ${ }^{13}$, y al mismo continuó dedicado muchos años tras el acceso al trono de Alfonso el Magnánimo, quien estuvo apremiado por la necesidad de contar cuanto antes con el dinero en sus manos para poder financiar su primera empresa de conquista en el Mediterráneo, la que inició con rumbo a Cerdeña en el año 1420. Para desesperación del monarca aragonés, sin embargo, los obstáculos que se interpusieron a la pronta transferencia del dinero desde Castilla fueron numerosos, de modo que hasta el año 1426 no pudo darse el proceso por concluso $^{14}$. Durante la mayor parte de este tiempo el arcediano de Niebla permaneció en la Corte castellana, donde se le consideraba formalmente como embajador del rey de Aragón, según este último hizo constar de forma expresa

\footnotetext{
${ }^{9} \mathrm{ACA}, \mathrm{C}$, reg. 2561, fol. 52, Poblet, 21-IV-1416. Para que intercediesen ante el infante Enrique escribió cartas sobre este mismo asunto a Diago Fernández de Vadillo, García Fernández Manrique, mayordomo del infante, y Fernán González de Avila, su canciller.

${ }^{10} \mathrm{ACA}, \mathrm{C}$, reg. 2561, fol. 72, Espluga de Francolí, 17-V-1416. Para que interceda ante el infante Juan escribe también una carta sobre este asunto al Adelantado de Castilla.

${ }^{11} \mathrm{ACA}, \mathrm{C}$, reg. 2562, fol. 174v, Valencia, 8-III-1418. Para que intercedan ante el infante escribe sobre este mismo asunto al doctor Fernando González, su canciller, y a García Fernández Manrique, su mayordomo mayor. Juan Ramírez de Toledo ya servía entonces al infante Enrique como recaudador mayor, pues así se hace constar en una nueva carta que sobre este mismo asunto volvió a escribir poco después Alfonso V a su hermano, ACA, C, reg.2564, fol. 5, Valencia, 16IV-1418.

${ }^{12}$ ACA, C, reg. 2949, fol. 5v, Uldecona, 11-V-1420. La reina María al rey de Castilla. El rey mi marido os ha enviado al arcediano de Niebla para cobrar cierta cantidad de dinero que quedaba por cobrar de la dote que se le había ofrecido a ella. Ahora, para que la resolución del asunto se acelere, el rey envía a Castilla a su aposentador mayor, Andres Fernández de Salvatierra. Le pide que dé lugar para que el negocio se resuelva pronto.

${ }^{13} \mathrm{ACA}, \mathrm{C}$, reg. 2663, fol. 141v, Barcelona, 1-X-1416. Alfonso V ordena al receptor general de sus derechos en el condado de Urgel que pague al arcediano de Niebla cierta cantidad de dinero para compensar los gastos que tuvo en el viaje a Castilla para cobrar la dote de la reina.

${ }^{14}$ Más detalles sobre la participación del arcediano en las negociaciones del cobro de la dote de Doña María en la Corte castellana en Máximo DIAGO HERNANDO, Los intereses económicos de la reina María esposa de Alfonso el Magnánimo, en el reino de Castilla, "Acta Historica et Arqueologica Medievalia”, 29 (2008), pp. 437-478. En particular. pp. 441-6.
} 
en alguna de sus cartas ${ }^{15}$. Y, aunque su misión principal era acelerar las gestiones para que se hiciese efectiva la transferencia del dinero de la dote, también se le encargó de algunos otros asuntos de muy variada índole. Como ejemplo ilustrativo de estas otras actuaciones de carácter menor cabe recordar que, cuando en 1421 Alfonso V escribió desde Mesina a la reina de Castilla, para solicitarle que continuase pagando la ración y quitación acostumbrada a un individuo llamado Lope González de Cuenca, pese a que éste se había ausentado de la Corte castellana para servirle a él en su armada, envió también cartas al arcediano de Niebla, además de a la aya y a una doncella de la referida reina, para que intercediesen ante ésta a fin de que accediese con más facilidad a lo que se le pedía ${ }^{16}$. Por otro lado, en esta etapa, también tuvo lugar su intervención en las negociaciones que se desarrollaron en Tarazona en 1425 para la liberación del infante Enrique ${ }^{17}$.

Concluida esta etapa de la actividad diplomática del arcediano en la Corte castellana, éste debió regresar a territorio aragonés, para encontrarse en persona con el rey Alfonso tras su regreso a la Península. Pero se trataría de una estancia breve, según se deduce de una carta que este monarca envió a Juan II de Castilla desde Valencia en septiembre de 1427, comunicándole que, para tratar sobre asuntos concernientes a ambos, al rey de Navarra y al infante Enrique, le iba a enviar en breve como embajador al referido arcediano ${ }^{18}$. Y, en efecto, en el transcurso del año 1427 éste regresó a Castilla, según nos lo atestigua una carta de Alfonso el Magnánimo que le envió desde Teruel el 9 de diciembre de ese año, en la que acusaba recibo de dos cartas que el propio arcediano le había enviado desde Medina del Campo y Valladolid ${ }^{19}$. Meses después Fernando Díaz de Toledo regresó a Aragón a entrevistarse con su señor el rey, quien de nuevo en agosto de 1428 le expidió salvoconducto para que viajase a Castilla a negociar en su nombre ciertos asuntos con el monarca castellano ${ }^{20}$.

Aunque la relación del arcediano de Niebla fue probablemente más estrecha y constante con Alfonso el Magnánimo, sobre todo en los períodos

\footnotetext{
${ }^{15}$ En carta que Alfonso V dirigió al arcediano de Niebla desde Cáller en 1421 le calificó expresamente como su "embajador en la Corte del rey de Castilla". ACA, C, reg. 2570, fol. 82v, Câller, 26-I-1421.

${ }^{16} \mathrm{ACA}, \mathrm{C}$, reg. 2570, fol. 165, Mesina, 16-VI-1421.

${ }^{17}$ Vid. Jerónimo ZURITA, Anales de la Corona de Aragón. Institución Fernando el Católico, Zaragoza, 1980, vol. 5, pp. 650-1. Informa este autor que los reyes de Aragón y Navarra se juntaron en los campos de la Torre de Araciel, del reino de Navarra, el lunes 3 de septiembre de 1425 , estando en su presencia el arzobispo de Tarragona, Pierres de Peralta, mayordomo mayor del rey de Navarra, Fernando Díaz de Toledo, arcediano de Niebla y Alcira, del Consejo del rey de Aragón, y el doctor Fortún Velázquez, del Consejo del rey de Castilla, y allí "declararon su determinacion y sentencia", acordándose que el infante Enrique fuese "francamente puesto en libertad".

${ }^{18} \mathrm{ACA}, \mathrm{C}$, reg. 2680, fol. 120v, Valencia, 16-IX-1427. En misma fecha concedió un salvoconducto al arcediano para que pudiese realizar sin inconveniente el viaje a la Corte castellana (Ibid, fol. 121v).

${ }^{19} \mathrm{ACA}, \mathrm{C}$, reg. 2677, fol. 43v y 56, Teruel, 9-XII-1427.

${ }^{20}$ ACA, C, reg. 2579, fol. 4v, Valencia, 7-VIII-1428. Vid. también Reg. 2863, fol. 38 , Valencia, 7-VîII-1428. Carta de Álfonso el Magnánimo a Juan II de Castilla, anunciándole el próximo envío del arcediano, a quien había informado de su intención
} 
en que éste permaneció en la Península, lo cierto es que su esposa, la reina María, también recurrió a sus servicios con notoria frecuencia. Así, al margen de las numerosas veces que tuvo que tratar con él cuando estuvo al cargo de la misión de acelerar los trámites para que se le transfiriese el dinero de su dote, sabemos de algunos otros encargos que le hizo, en ocasiones para asuntos de su estricto interés personal. En concreto, por ejemplo, en 1421 le dio instrucciones para que tratase de conseguir que el rey de Castilla siguiese abonando a su médico, el maestre Francisco de Burgos, la quitación que le correspondía, a pesar de que no podía desempeñar sus funciones por encontrarse permanentemente ausente de la Corte castellana ${ }^{21}$. Este individuo, en efecto, pese a ser médico del rey de Castilla, y percibir quitación como tal a cargo del erario castellano, había pasado a Aragón en compañía de María, cuando ésta había contraído matrimonio con su primo Alfonso. Pero como su ausencia se prolongaba, los contadores de cuentas del rey de Castilla decidieron finalmente dejar de librarle dicha quitación, por lo cual en 1421 maestre Francisco solicitó a su señora Doña María que le permitiese regresar a la Corte castellana. La reina, sin embargo, no veía con buenos ojos que éste la abandonase, porque consideraba que sabía más sobre sus enfermedades que cualquier otro médico del reino, y por ello entendía que su permanencia a su lado era absolutamente necesaria.

Además, Doña María también se dirigió en repetidas ocasiones al arcediano, cuando éste se encontraba en Castilla, para que favoreciese a algunos de sus servidores que mantenían intereses en territorio castellano, y que solían ser también originarios de Castilla. Así, por ejemplo, en 1422 le encareció repetidamente que tuviese por recomendado a un miembro de su capilla, Diego Gómez de Castro, originario de la diócesis de Burgos ${ }^{22}$. Y unos años antes, en agosto de 1422, le escribió para que intercediese a favor de otro destacado servidor suyo, el capellán de su capilla, García Gómez de Riaza, a quien le estaba siendo disputada la posesión de un beneficio por un criado del arcediano de Calatrava llamado Alonso Sánchez de Burgos ${ }^{23}$. Por fin, por poner un tercer ejemplo, cabe recordar que en 1427 le encargó que trabajase para conseguir el asentimiento del cabildo segoviano al nombramiento de su médico, el ya mencionado maestre Francisco de Burgos, como canónigo de la catedral de Segovia, que por su intercesión acababa de efectuar el obispo de Segovia ${ }^{24}$.

Por lo demás, precisamente porque la reina María solicitó reiteradamente los servicios del arcediano de Niebla, también se preocupó por tratar de conseguir para él beneficios eclesiásticos, como forma de recompensarle

${ }^{21} \mathrm{ACA}, \mathrm{C}$, reg. 3164, fol. 125v, Barcelona, 15-XI-1421. Carta de la reina María al arcediano de Niebla.

${ }^{22}$ ACA, C, reg. 2962, fol. 9v, Barcelona, 24-XI-1422.

${ }^{23} \mathrm{ACA}$, C, reg. 3108, fol. 88v, Zaragoza, 3-VIII-1420. Sobre este mismo asunto Doña María escribió también al deán de Toledo y al propio arcediano de Calatrava. Niebla.

${ }^{24} \mathrm{ACA}, \mathrm{C}$, reg. 3170, fol. 62v, Valencia 10-VI-1427. Carta de la reina María al arcediano de 
por su constante buena disposición para servirla. Así cabe destacar que en 1426 presentó una petición al Papa para que se le concediese algún nuevo beneficio $^{25}$, realizando gestiones al mismo tiempo para que pudiese ocupar el arcedianato que había quedado vacante por muerte de un canónigo de la catedral de Valencia llamado P. Guitard ${ }^{26}$.

En muy mayor medida que Doña María, no obstante, fueron su suegro y su marido los que más se movilizaron para conseguir beneficios para el que consideraban uno de sus más fieles servidores. No sabemos si Fernando de Antequera tendría alguna intervención a la hora de conseguir que se le nombrase para la dignidad de arcediano de Niebla en la catedral de Sevilla, que ya ocupaba en enero de 1415, fecha en que el Papa Benedicto XIII le hizo merced, a súplica precisamente de este monarca, de una canonjía vacante en la iglesia de Toledo por muerte de Lope Rodríguez de Cuenca ${ }^{27}$. No fue, por lo demás, ésta la única intervención de Fernando de Antequera a favor del arcediano, puesto que ya con anterioridad, nada más acceder al trono aragonés en 1412, nos consta que solicitó al Papa que le proveyese del obispado de Ávila, que acababa de quedar vacante, prefiriéndolo al arcediano de Almazán, a quien él mismo había propuesto con anterioridad para cubrir la vacante ${ }^{28}$. Pero en esta ocasión sus gestiones no dieron el resultado apetecido, y el arcediano no pudo alcanzar la anhelada dignidad episcopal.

Tras la muerte de Fernando de Antequera su hijo Alfonso el Magnánimo también desplegó una notable actividad a fin de conseguir beneficios eclesiásticos para el arcediano. Así nos consta que en 1418 a petición suya el Papa Martín V le concedió el arcedianato de Alcira, en la catedral de Valencia ${ }^{29}$. Ese mismo año encargó al maestre racional de la Corte, Leonart des Sos, que tuviese por recomendados en la Corte Romana los negocios del arcediano ${ }^{30}$. Y, según reconoció en una carta que por aquellas mismas fechas dirigió a Gonzalo García de Santa María, refrendario del Papa, estaba procurando conseguir que obtuviese gracias a su mediación hasta 3.000 florines de renta en beneficios eclesiásticos, para lograr lo cual había presentado varias súplicas al Papa, aunque hasta entonces con poco éxito, ya que sólo había logrado que se le concediese el arcedianato de Alcira, que rentaba unos 1.000 florines. Por ello, seguía informando en dicha carta, tenía proyectado que a Gonzalo García de Santa María se le proveyese del primer obispado que quedase vacante en sus reinos, con condición de que a continuación le sucediese en todos sus beneficios el arcediano de Niebla, para

${ }^{25}$ ACA, C. reg. 2967, fol. 24v, Valencia, 1-I-1426.

${ }^{26}$ ACA, C. reg. 2967, fol. 21v, Valencia, 1-I-1426.

${ }^{27}$ Vicente BELTRÁN DE HEREDIA, op. cit., doc. 498, Valencia 29-I-1415.

${ }^{28}$ ACA, C, reg.2381, fol. 2v, Maluenda 26-VII-1412. En esta súplica de Fernando de Antequera al Papa hace constar que ya con anterioridad, presumimos que siendo regente de Castilla, le había escrito repetidas veces solicitándole que promoviese al arcediano de Niebla a algún obispado en el reino de Castilla.

${ }^{29}$ Vicente BELTRÁN DE HEREDIA, op. cit. doc. 553, Constanza, 16-IV-1418.

${ }^{30} \mathrm{ACA}, \mathrm{C}$, reg. 2562, fol. 163, Valencia, 12-I-1418. 
que de este modo se pudiese alcanzar la renta de los 3.000 florines anuales que para él ambicionaba. Y, para que este objetivo pudiese alcanzarse con más facilidad, le encareció en la referida carta que conferenciase con el Papa sobre este negocio ${ }^{31}$. Por fin, también la propia reina doña Leonor, después de enviudar de Fernando de Antequera, se sumó a la larga lista de los que intercedieron a favor del arcediano de Niebla ante las oportunas instancias en el seno de la Iglesia en asuntos beneficiales. Así lo demuestra por ejemplo la prórroga que se le concedió a éste en 1424 para que durante otro septenio pudiese continuar percibiendo íntegros los frutos de sus beneficios, a pesar de estar ausente. Dicha prórroga le fue concedida, en efecto, en respuesta a una petición presentada por la propia reina Leonor, y se justificó con el argumento de que si no permanecía en las iglesias donde estaba beneficiado era porque se encontraba al servicio de esta reina como su capellán mayor, aunque de hecho sabemos que eran otras muy diversas tareas las que desempeñaba, no tanto al servicio de Leonor como de sus hijos ${ }^{32}$.

Por lo demás, Alfonso el Magnánimo y su familia tenían motivos para estar agradecidos del arcediano de Niebla no sólo por los servicios de carácter político y diplomático que les prestó, sino que también recurrieron a él con relativa frecuencia para que les prestase dinero, del que los Trastamara aragoneses siempre estuvieron tan apremiantemente necesitados. Así, nos consta que en 1423 este monarca recibió prestados de nuestro personaje 3.090 florines de Aragón, que le fueron entregados en su nombre por Alvaro Garavito, baile general de Aragón, y Antón de Fulleda, criado del propio arcediano. Dicha cantidad le fue devuelta mediante libranza sobre el dinero que había de cobrar de la dote de la reina ${ }^{33}$. Más adelante, en 1426, tenemos noticia de que la viuda de Fernando de Antequera, la reina Leonor de Alburquerque, ordenó al arcediano que donase a su hijo el rey Alfonso ciertas joyas de oro que pesaban 17 marcos, y a su hija la infanta Leonor, 50 marcos de plata dorada. Estas joyas las tenía en prenda el arcediano, que las había depositado en el monasterio de Guadalupe, por lo que no descartamos que en origen hubiesen pertenecido a la familia real aragonesa, que se las habría entregado como garantía de la devolución de un préstamo que éste les hubiese efectuado $^{34}$. Por fin, también tenemos constancia de que durante la estancia en Tarazona en 1425 para decidir sobre la prisión del infante Enrique, a la que ya nos hemos referido con anterioridad, el arcediano prestó 800 doblas a

\footnotetext{
${ }^{31} \mathrm{ACA}, \mathrm{C}$ reg. 2564, fol. 153, Fraga, 7-XII-1418. Dado que el arcediano era ya canónigo de Toledo, y Gonzalo García de Santa María también tenía una canonjía en Toledo le propuso que tratase de que ésta fuese para el chantre de Cartagena, capellán del rey de Castilla.

${ }^{32}$ Noticia del documento, fechado en Roma, 1-IV-1424 en Vicente BELTRÁN DE HEREDIA, op. cit. doc. 693 .

${ }^{33}$ ACA, C, reg. 2674, fol. 70, Nápoles 22 II 1423. Carta de Alfonso V facultando al arcediano para que recuperase la cantidad prestada tomando el dinero preciso de lo que recaudase de la dote de la reina María, o de otras cantidades de moneda que hubiese disponibles en la Corte, para lo cual había cursado las ordenes pertinentes al maestre racional de la Corte.

${ }^{34} \mathrm{ACA}, \mathrm{C}$, reg. 2682, fol. 105v Valencia, 23-V-1426. Carta a Francisco d'Arinyo encargándole que solicite al rey de Castilla un salvoconducto para que Alfonso de Palma y a Pedro de Astiasso puedan viajar seguros a Aragón con las joyas y plata que les ha de entregar el arcediano de Niebla.
} 
Alfonso el Magnánimo, que éste se comprometió a devolverle en el plazo más breve posible, ofreciéndole garantías de que el dinero cobrado de la dote de su mujer, la reina María, quedaría inmovilizado hasta que le hubiese devuelto todo el dinero que le adeudaba por razón de éste y otros préstamos que le había efectuado con anterioridad ${ }^{35}$.

Este reiterado recurso al arcediano para que adelantase dinero nos lleva a sospechar, por tanto, que fuese precisamente su disponibilidad de recursos financieros, por su pertenencia a una familia de origen judeoconverso con acreditada experiencia en el mundo de los negocios, la que más pesó en el ánimo de Alfonso el Magnánimo a la hora de encargarle de la misión de acelerar los trámites en la Corte castellana para el cobro de la dote de su esposa, y asegurar la transferencia del dinero a las plazas de la Corona de Aragón donde él lo precisaba para la financiación de sus empresas militares.

\section{LOS HERMANOS FERNANDO Y GARCÍA GÓMEZ DE RIAZA, CLÉRIGOS DE LA CAPILLA DE LA REINA MARÍA}

Nada de sorprendente tiene que la reina María, dado su origen castellano, contase entre sus servidores con numerosos individuos que eran súbditos del rey de Castilla, aunque no resulta fácil distinguir los que la acompañaron a Aragón cuando abandonó la Corte castellana para contraer matrimonio con su primo de aquellos otros que ya se encontraban con anterioridad en la Corte aragonesa, por formar parte del círculo de servidores de Fernando de Antequera y su familia. Entre estos castellanos ocuparon un lugar destacado dos hermanos, que compartieron la condición de clérigos y capellanes al servicio de Doña María, a los cuales ésta recurrió con frecuencia para que representasen sus intereses en misiones diplomáticas a la Corte castellana. Nos referimos a Fernando y García Gómez de Riaza, hermanos que presumimos debían ser originarios de la villa segoviana de Riaza, aunque prácticamente nada sabemos sobre su procedencia social y su biografía, salvo que Fernando fue también capellán del rey de Castilla, Juan II, y llegó a ocupar una canonjía en la catedral de Toledo. En cualquier caso, no cabe duda de que su rango sociopolítico era notoriamente inferior al del arcediano de Niebla, y así se puso de manifiesto en el hecho de que las misiones diplomáticas que les encomendó la reina María fueron regularmente de menor nivel que las desempeñadas por Fernando Álvarez de Toledo.

De los dos hermanos fue Fernando de Riaza el que desarrolló una más dilatada e intensa actividad al servicio de su señora, la reina de Aragón, que le llevó a permanecer durante largas temporadas en el reino de Castilla, de donde era originario, y donde, como hemos adelantado, logró una canonjía en

\footnotetext{
${ }^{35}$ En carta dirigida por Alfonso el Magnánimo a Don Abrahem Bienveniste en febrero de 1426 se hace constar que Alfonso se había comprometido en Tarazona a devolver al arcediano de Niebla 800 doblas, que éste le había prestado en dicha ciudad aragonesa, y otras cantidades que le adeudaba. ACA, C, reg. 2681, fol. 50v, Valencia, 8-II-1426.
} 
la catedral de Toledo, que no nos consta que llegase a servir en ningún momento personalmente. Una de sus primeras misiones en territorio castellano de las que tenemos noticia se inició a fines del año 1427, cuando Doña María le encargó de que averiguase el valor en maravedíes al que se habían cotizado en Castilla entre los meses de julio y noviembre de ese año los reales de Valencia y los florines de Aragón, porque ella precisaba disponer de esta información para poder ajustar cuentas con las personas que habían tenido cargo de cobrar sus rentas castellanas, cuyo monto estaba fijado en maravedíes, y transferírselas a plazas de la Corona de Aragón ${ }^{36}$. Poco tiempo después, en 1429, tuvo que viajar de nuevo a Castilla para atender negocios relacionados con la recaudación del la renta del "mantenimiento", de 400.000 mrs. anuales, que el monarca castellano Juan II tenía asignada a su hermana, la reina de Aragón ${ }^{37}$. Pero en esta ocasión Doña María le encargó también de que hiciese entrega a su hermano de unos caballos que había decidido enviarle como regalo ${ }^{38}$.

Para la primera mitad de la década de 1430 no hemos encontrado apenas noticias sobre la actividad desempeñada por Fernando de Riaza, hasta que en 1436 él y su hermano, García Gómez de Riaza, fueron nombrados por doña María como sus procuradores para demandar en Castilla cualquier cuantía de dinero que se le adeudase a ella por cualquier concepto, pasando a asumir un cargo que hasta entonces había ejercido con exclusividad el relator Fernando Díaz de Toledo, primo del arcediano de Niebla, e individuo con notable influencia en la Corte castellana ${ }^{39}$. Cuando se efectuó el nombramiento, en febrero de 1436, consta que Fernando se encontraba en territorio aragonés en compañía de la reina, concretamente en Monzón. Es probable que poco después partiese para Castilla a desempeñar su nueva misión como procurador, pero dos años más tarde, en abril de 1438, lo volvemos a encontrar en la Corte aragonesa, pues entonces de nuevo recibió el encargo de la reina María de desplazarse a la Corte castellana para entrevistase personalmente con el rey Juan II, a fin de tratar con él de ciertos asuntos en su nombre, probablemente de naturaleza política, aunque desconocemos en concreto de cuáles se trataba ${ }^{40}$. A partir de esa fecha parece que permaneció durante prolongados períodos de tiempo como embajador de doña María en la Corte de su hermano el rey de Castilla. Un documento de

${ }^{36} \mathrm{ACA}, \mathrm{C}$, reg. 3170, fol. 102, Teruel, 2-XII-1427. Carta de la reina María a los oficiales del reino de Castilla, comunicándoles el inminente viaje del fiel de su capilla, Fernando de Riaza, y el objetivo de su misión.

${ }^{37}$ Más información sobre esta renta y los problemas que planteó su recaudación en, Máximo DiAGO HERNANDO, Los intereses economicos...

${ }^{38} \mathrm{ACA}, \mathrm{C}$, reg. 2967, fol. 154v, Zaragoza, 3-X-1429. Carta de la reina María al relator Fernando Díaz de Toledo, anunciándole el próximo viaje de Fernando de Riaza a la Corte castellana.

${ }^{39} \mathrm{ACA}, \mathrm{C}$, reg. 2975, fol. 185, Monzón, 12-II-1436. Nombramiento por doña María como sus procuradores especiales de sus capellanes García Gómez de Riaza, ausente, y Fernando de Riaza, presente El nombramiento del relator como procurador especial había tenido lugar en 1430. Vid. ACA, C, reg. 2967, fol. 167v, Ulldecona, 16-V-1430.

${ }^{40}$ ACA, C, reg. 3177, fol. 3, Barcelona, 16-IV-1438. 
junio de 1443 nos confirma, en efecto, que en aquellos momentos Fernando de Riaza y el provincial de los dominicos residían en la Corte castellana como embajadores de esta reina, la cual informó entonces, muy preocupada, al recaudador de la renta de su mantenimiento en Castilla, Pedro Martínez de Castro, que estos dos individuos estaban padeciendo allí mucha necesidad y penuria, porque no tenían dinero para poder gastar y no encontraban a nadie que estuviese dispuesto a prestárselo. Y por ello le urgió a dicho recaudador para que les entregase lo antes posible algún dinero ${ }^{41}$. Otros muchos documentos cancillerescos de ese año confirman la presencia de Fernando de Riaza en la Corte castellana, donde estaba negociando asuntos de cariz preferentemente económico, relacionados con el reparto de la herencia de la difunta infanta Catalina, que, dado que había muerto sin hijos, correspondía por mitad a sus dos hermanos supervivientes, el monarca castellano Juan II y la propia Doña María. Antes de repartir nada, había de procederse, sin embargo, a pagar todas las deudas que había dejado la difunta, y cumplir con las disposiciones de carácter piadoso que había incluido en su testamento, que también requerían una importante dotación financiera. Y a todos estos asuntos nos consta que estaba dedicando su atención el capellán Fernando de Riaza en Castilla en el año 1443.

Después de esta prolongada estancia en tierras castellanas, debió regresar a Aragón, desde donde de nuevo a mediados de 1444 Doña María le ordenó que partiese a la Corte de su hermano Juan II, en esta ocasión para desempeñar una misión de cariz aparentemente más político, pues en la carta que dirigió a este último, comunicándole la próxima llegada de su capellán, le hacía saber que se lo enviaba "para procurar paz y sosiego" ${ }^{2}$. Entonces se debió iniciar otra prolongada permanencia de nuestro personaje en Castilla, donde continuó desempeñando el cargo de procurador al servicio de la reina María, dedicándose de forma preferente a resolver negocios relacionados con el cobro de las rentas que a ésta le correspondía percibir en Castilla, y la resolución de los problemas que estaba planteando el pago de las deudas que había dejado la difunta infanta Catalina, aún sin terminar de resolver a la altura del año $1453^{43}$. Pero, al mismo tiempo, nos consta que su señora también esperaba de él que la mantuviese puntualmente informada sobre la evolución de la coyuntura política en la Corte castellana. Buena prueba de ello nos la proporciona la carta que le envió en junio de 1453 , en la que le recriminaba porque no le había informado de los graves acontecimientos que estaban ocurriendo entonces en Castilla, donde había tenido lugar nada menos

\footnotetext{
${ }^{41}$ ACA, C, reg. 3189, fol. 16, Tortosa, 21-VI-1443.

${ }^{42}$ ACA, C, reg. 3187, fol. 175v, Valencia, 5-VIII-1444.

${ }^{43}$ En carta que escribió la reina María al cardenal de Hostia en este año le manifestaba que había pedido al rey de Castilla que pagase la mitad de las cantidades que ella había abonado a los servidores y familiares de la infanta Catalina. Por ello pidió al cardenal que enviase a su capellán Fernando de "Riaza, canónigo de Toledo, quien al parecer se encontraba en la Corte del rey de Castilla, un "memorial autentico" de las cantidades que por este concepto había pagado ella, y a quién, para que luego el rey de Castilla le abonase la mitad. ACA, C, reg. 3214, fol. $2 \mathrm{v}$, Barcelona, 14-VII-1453.
} 
que la ejecución del otrora todopoderoso Condestable Don Álvaro de Luna. Pero, además de recriminarle, también le exigió que inmediatamente le escribiese, informándola con todo detalle de los hechos relevantes que habían tenido lugar recientemente en Castilla ${ }^{44}$.

La actividad desarrollada por García Gómez de Riaza al servicio de Doña María presenta muchas similitudes con la de su hermano Fernando. Así, la mayor parte de sus misiones en territorio castellano tuvieron como principal objeto hacerse cargo de asuntos relacionados con la recaudación de las rentas que esta reina debía percibir en Castilla. Así, ya en 1431, le designó como su procurador y "hacedor especial" para que cobrase todas las cantidades de dinero que se le adeudaban a ella en territorio castellano y que debían haberse cobrado en los años anteriores ${ }^{45}$. Más adelante, en 1436, él y su hermano Fernando fueron designados conjuntamente procuradores con esta misma misión de cobrar deudas. En 1444 a García Gómez de Riaza nos lo encontramos volcado en la tarea de negociar en la Corte castellana el establecimiento de un nuevo procedimiento que facilitase el cobro efectivo de las rentas que Doña María tenía asignadas en Castilla, en la que, según le confesó a ésta en una carta, estaba tropezando con enormes dificultades ${ }^{46}$. Y, por fin, en 1450 fue designado para hacerse cargo de la recaudación de las cantidades de dinero que la reina de Aragón tenía situadas en los puertos aduaneros de Requena, Moya, Almansa, Yecla y Murcia, y en otras rentas de la Real Hacienda castellana en los obispados de Cuenca, Cartagena. Osma, Sigüenza y Calahorra, con atribuciones para poder mudar la situación de las cantidades que estimase oportuno a rentas percibidas en la ciudad de Sevilla y su arzobispado ${ }^{47}$.

Pero, al margen de estas misiones relacionadas con la recaudación de dinero, también asumió por encargo de Doña María el desempeño de algunas otras más delicadas, que exigían llevar a cabo negociaciones, y mover hilos, en la Corte castellana a fin de alcanzar determinados objetivos, que, por supuesto, solían tener siempre una importante contrapartida económica. Así, a título ilustrativo, sirva recordar que en 1431 esta reina le encomendó, entre otras varias misiones, que se emplease en tratar de conseguir que la asignación

${ }^{44} \mathrm{ACA}, \mathrm{C}$, reg. 3214, fol. 1v, Barcelona, 23-VI-1453.

${ }^{45}$ ACA, C, reg. 3172, fol. 6v, Barcelona, 22-V-1431.

${ }^{46}$ Vid. Carta de la reina María a su hermano el rey de Castilla en ACA, C, reg. 3189, fol. 189, Valencia, 30-III-1444. Se refiere a una carta que le había escrito informándole de "la indisposición que hay al presente en el asentar del mantenimiento de la reina".

${ }^{47}$ ACA, C, reg. 3202, fol. 114v, Perpiñán, 24-IV-1450. Para facilitar su misión, doña María envió cartas de creencia en su favor al rey de Castilla y a una larga serie de miembros de la sociedad política castellana, en su mayoría individuos con influencia en las zonas fronterizas con la Corona de Aragón, tales como Don Pedro de Mendoza, señor de Almazán, el relator, doctor Fernán Díaz de Toledo; el contador Alfonso Alvarez de Toledo; Alonso de Barrientos, Lope de Alarcón, el corregidor de Soria, Martín Pérez Calaforrano, Fernán Picazo, el corregidor y alcaldes de Cuenca, el arcediano de Cuenca, alcalde y oficiales de Requena, y Carlos de Arellano, señor de Ciria y Borobia. El tenor de las cartas de creencia en ACA, C, reg. 3202 fol. 118, Perpiñán, 30-IV-1450. La carta de creencia enviada al obispo de Cuenca Íbid. fol. 121. 
que el monarca castellano había concedido a su médico, maestre Francisco de Burgos, quien al parecer acababa de morir, le fuese traspasada a ella ${ }^{48}$.

Los muchos servicios que los hermanos Fernando y García Gómez de Riaza prestaron a la reina María, en particular durante sus prolongadas estancias en Castilla, no pudieron ser compensados directamente por ésta mediante el abono de importantes cantidades de dinero en forma de salarios o quitaciones. Por el contrario, la documentación cancilleresca proporciona claros indicios que demuestran que la crónica penuria en que se desenvolvían las finanzas de esta desgraciada reina le impidió remunerar con un mínimo de dignidad a sus servidores, en particular a los que defendían sus intereses en Castilla. Ya hemos referido cómo en 1443 la propia Doña María reconoció en una carta que sus dos embajadores permanentes en la Corte castellana, Fernando de Riaza y el provincial de los dominicos, estaban padeciendo allí mucha necesidad y penuria. Pero no fue la única ocasión en que se planteó este problema, pues ya muchos años antes, en 1432, cuando envió como embajador a la Corte de su hermano a Nicolau Rocha, le dio instrucciones para que, en caso de que se encontrase en ella con Mosén García Gómez de Riaza le explicase que, debido a las grandes necesidades de su propia Corte y a los pocos ingresos de que disponía, le resultaba necesario restringir los gastos, y por ello "no pot soplir als seus servidors de ço que voldría"49.

Precisamente por esto, para compensar la falta de remuneraciones en forma de sueldos, quitaciones y ayudas de costa, percibidos en dinero contante y sonante procedente de la tesorería aragonesa, Doña María se empleó a fondo para conseguir para sus dos capellanes, los hermanos Riaza, el mayor número posible de beneficios eclesiásticos. Y, al mismo tiempo, hizo cuantas gestiones fue preciso para asegurarles la percepción de las rentas anejas a dichos beneficios, cuando tropezaron con problemas para cobrarlas como consecuencia de que no servían los beneficios con sus personas, residiendo el tiempo necesario en las correspondientes iglesias.

Así, en las instrucciones que transmitió al embajador que en 1442 envío a su marido a Italia, figuraba el encargo a éste para que escribiese al Papa solicitándole la concesión de beneficios en Aragón o en Castilla para su capellán Fernando de Riaza, pues, habiendo sido éste un buen servidor suyo durante mucho tiempo, en aquellos momentos sólo disponía de beneficios "de poca suma", es decir, que proporcionaban escasos ingresos, y que además estaban dispersos en muy diversos lugares ${ }^{50}$. Ella misma, por su parte, en 1446 dirigió una súplica al cardenal de Valencia, solicitándole que intercediese en la Corte romana para que se le concediese a este mismo capellán una canonjía que iba a quedar vacante en la iglesia de Toledo por promoción del obispo de Sigüenza a la iglesia de Toledo, y nombramiento para obispo de

${ }^{48} \mathrm{ACA}, \mathrm{C}$, reg. 3172, fol. 45v, Barcelona, 3-XII-1431. Instrucciones de doña María a su capellán, García Gómez de Riaza, quien se encontraba entonces en Castilla.

${ }^{49} \mathrm{ACA}, \mathrm{C}$, reg. 3172, fol. 83v.

${ }^{50} \mathrm{ACA}, \mathrm{C}, 3185$, fol. 150 . 
Sigüenza de un canónigo de Toledo ${ }^{51}$. Y dos años más tarde pudo comunicar al arzobispo de Toledo que, gracias a una súplica que ella había elevado al Papa, Fernando de Riaza había obtenido de éste una carta expectativa en ese arzobispado, por lo que le rogaba que lo tuviese por recomendado y le proporcionase todo cuanto favor y ayuda estuviese a su alcance ${ }^{52}$. Por lo demás, sus intervenciones para conseguir beneficios para los hermanos Riaza no se circunscribieron exclusivamente a las instancias eclesiásticas, pues también trató de premiarles con beneficios cuya provisión era de patronato laico. Como prueba recordaremos la carta que en 1421 dirigió al baile general de Valencia para que se asegurase de que García Gómez de Riaza obtenía el beneficio de San Juan de la capilla del Palau Reyal de Valencia ${ }^{53}$.

Los testimonios que proporciona la documentación cancilleresca sobre intervenciones de doña María a favor de los hermanos Riaza, para que se les pagasen las rentas de sus beneficios, o se les respetasen éstos cuando algún otro candidato trataba de arrebatárselos, son también relativamente abundantes, por lo que nos limitaremos a dar cuenta sólo de algunos, a título meramente ilustrativo. Así, cabe recordar que en 1421 escribió al arzobispo de Toledo, rogándole que concediese a García Gómez de Riaza dispensa de hacer residencia personal en un beneficio que había obtenido en una iglesia de su arzobispado, en el que estaba regulado que todo beneficiado había de hacer residencia personal durante al menos cuatro meses cada año ${ }^{54}$. Pero, ya el año anterior, había tenido que intervenir a favor de este mismo capellán, probablemente por razón del mismo beneficio del arzobispado de Toledo, debido a que la posesión del mismo le estaba siendo disputada por un criado del arcediano de Calatrava llamado Alonso Sánchez de Burgos ${ }^{55}$. En otra ocasión intervino para que un servidor del obispo de Barcelona no le molestase en la posesión de la rectoría de Mediona, de la que había sido proveído $^{56}$. Y en 1453 se dirigió al obispo de Zamora, para rogarle que prescindiese de recurrir ante la Corte Romana una sentencia que se había pronunciado a favor de García Gómez de Riaza, que disputaba un beneficio en San Martín de la Vega con un familiar y servidor del mencionado obispo, llamado Juan Gutiérrez de Sigüenza ${ }^{57}$. Por fin, por poner un ejemplo relativo a intervenciones a favor del otro hermano, Fernando de Riaza, recordaremos que entre las instrucciones que dio a Antoni de Mayans y Alfonso López de La Muela, embajadores enviados a Castilla en 1443, figura una encargándoles

\footnotetext{
${ }^{51}$ ACA, C, reg. 3191, fol. 184v, Valencia 1-III-1446.

${ }^{52}$ ACA, C, reg. 3201, fol. 208, Barcelona, 20-VI-1448. Cartas con idéntico contenido dirigió también al cabildo de Toledo, al arcediano de Toledo, al obispo de Cuenca y al cabildo de

${ }^{53}$ ACA, C, reg. 3109, fol. 158, Barcelona, 17-X-1421.

${ }^{54} \mathrm{ACA}, \mathrm{C}$, reg. 3109, fol. 77, Tortosa, 27-V-1421. Idéntica súplica dirigió en la misma fecha al arcediano de Calatrava.

${ }^{55} \mathrm{ACA}, \mathrm{C}$, reg. 3108, fol. 88v, Zaragoza, 3-VIII-1420. Cartas de Doña María al arcediano de Calatrava, al arcediano de Niebla y al deán de Toledo.

${ }^{56}$ Carta de la reina María al obispo de Barcelona en ACA, C, reg. 3109, fol. 44.

${ }^{57}$ ACA, C, reg. 3215, fol. 58v, Barcelona, 22-VII-1453.
} 
de solicitar que se restituyesen a este su capellán, o a su procurador, las rentas de dos préstamos suyos en el obispado de Cartagena, las cuales le habían sido tomadas por algunos servidores del infante Enrique ${ }^{58}$.

Consciente quizás de que los beneficios eclesiásticos no representaban suficiente recompensa para personas que habían estado a su servicio durante tanto tiempo, Doña María también hizo algunas gestiones por tratar de conseguir que éstos consiguiesen mercedes de la propia Monarquía castellana, habida cuenta que, según todos los indicios, los dos hermanos terminaron por quedarse de forma permanente en Castilla, sin dejar por ello de permanecer al servicio de la reina de Aragón. Así, cabe destacar que en 1453 encargó a su tesorero Galcerán de Oliver, enviado como embajador al rey de Castilla, que solicitase a éste que tuviese por especialmente recomendados a Fernando y García de Riaza, Gonzalo de Ferrera y Luis Darça, y, en premio a los servicios que continuamente le prestaban a ella, los quisiese "beneficiar y proveer en tal forma que pudiesen pasar su vida según su condición" ${ }^{59}$. Por su parte, ya en 1448 había intercedido ante su hermano a favor de Fernando de Riaza, rogándole que no dejase de pagarle el sueldo o ración que le tenía asignado como capellán, aunque estuviese ausente de la Corte castellana, mientras permaneciese al servicio de ella, como entonces lo estaba ${ }^{60}$. Y, en este afán por tratar de favorecer la suerte de sus capellanes en Castilla, recurrió también a miembros de la alta nobleza castellana, a los que solicitó de forma explícita que procurasen favorecerlos en cuanto estuviese a su alcance, como bien pone de manifiesto una carta que con este objeto dirigió en 1453 a la condesa de San Esteban ${ }^{61}$.

\section{Maestro Francisco de BuRgos: UN MÉDICO CASTELLANO \\ AL SERVICIO DE LA REINA DE ARAGÓN}

Además de los tres clérigos hasta ahora considerados, doña María tuvo a su servicio algunos otros de origen castellano por los que mostró una evidente predilección. Entre ellos cabe destacar a maestre Francisco de Burgos, que tuvo en común con el arcediano de Niebla su condición de médico que pertenecía al estamento clerical. A diferencia de éste, sin embargo, sus servicios a la reina María se circunscribieron exclusivamente al ámbito de la práctica de la medicina, pues no tenemos noticia de que recurriese a él en ninguna ocasión para el desempeño de misiones de carácter político o diplomático. A lo sumo, con ocasión de alguno de sus viajes a Castilla, la reina se limitó a encargarle negocios de carácter más prosaico,

\footnotetext{
${ }^{58} \mathrm{ACA}, \mathrm{C}$, reg. 3189, fol. 126.

${ }^{59} \mathrm{ACA}, \mathrm{C}$, reg. 3214, fol. 32v, Barcelona, 22-IX-1453.

${ }^{60}$ ACA, C, reg. 3202, fol. 5v, Perpiñán, 30-XI-1448. Instrucciones de la reina María a su embajador a la Corte del rey de Castilla, Pedro García de Zamora.

${ }^{61} \mathrm{ACA}, \mathrm{C}$, reg. 3215, fol. 100, Valladolid, 3-XII-1453.
} 
como hizo, por ejemplo, a comienzos del año 1425, cuando le pidió por carta que hiciese gestiones en la ciudad de Burgos para recoger un "cortinatge" que su camarero había encargado en dicha ciudad, y lo trajese después consigo a su regreso a la Corte aragonesa ${ }^{62}$.

En cualquier caso, parece que se trató de una persona con sólida formación intelectual, pues, además de ser maestro en artes y medicina, ostentó el título de bachiller en Santa Teología. Este hecho pudo facilitar su carrera dentro de la Iglesia, que cabe calificar de afortunada, ya que, pese a que, según todos los indicios, se dedicó de forma prácticamente exclusiva a la práctica de la medicina, y más en particular a cuidar de la salud de la reina de Aragón, llegó a acumular un número importante de beneficios eclesiásticos en lugares muy dispares. En concreto, sabemos que en 1425 ya poseía los siguientes: el arcedianato de Vallespir, en la catedral de Elna, una canonjía en la catedral de Barcelona, otra en la de Tarazona, una pensión anual de 150 florines de Aragón sobre los frutos del priorato de la Orden del Santo Sepulcro de Calatayud, el arciprestazgo de Tuili, en la isla de Cerdeña, una expectativa a una canonjía en la catedral de Burgos y a otra en la colegiata de Santa María de Valladolid ${ }^{63}$. Pero a partir de esa fecha su señora Doña María continuó esforzándose por tratar de conseguir que a esta lista se sumasen otros, todo por tener contenta a la persona que, en su opinión, estaba más capacitada para cuidar de su frágil salud. Así, ya en 1425 escribió al cardenal de Foix solicitándole para maestre Francisco la rectoría de la iglesia de Ternils, en la diócesis de Valencia, vacante por muerte de Juan Bertrand, camarlengo del cardenal de Sant Angelo ${ }^{64}$. Y al año siguiente solicitó para él al Papa una canonjía en la catedral de Toledo ${ }^{65}$, a la vez que dirigió numerosas cartas a personajes influyentes residentes en Corte Romana para que intercediesen ante el Papa a favor suyo ${ }^{66}$. Por otra parte, también hizo gestiones en esta misma línea en la Corte castellana, como nos testimonia la carta que dirigió en 1425 a su hermano el rey Juan II, en la que además de pedirle que escribiese al Papa, intercediendo a favor de maestre Francisco, le rogó que nombrase a éste como capellán suyo, asignándole el correspondiente sueldo, que en buena lógica habría de sumarse al que ya percibía como físico del monarca castellano, pese a que, debido a su permanencia en la Corte aragonesa, no ejercía como tal, ni se esperaba tampoco que fuese a ejercer como capellán ${ }^{67}$.

${ }^{62}$ ACA, C, reg. 2678, fol. 147v, Zaragoza, 17-III-1425.

${ }^{63}$ ACA, C, reg. 2967, fol. 9, Tarazona, 21-XI-1425.

${ }^{64}$ Íbidem.

${ }^{65} \mathrm{~A}, \mathrm{C}$, reg. 3170, fol. 9v, Valencia, 12-XI-1426. Carta de la reina María al Papa suplicándole la provisión de dicha canonjỉa. También escribió una carta al obispo de Tuy para que renunciase en maestre Francisco la canonjía que él poseía en Toledo (Ibídem. fol. 10).

${ }^{66} \mathrm{Cabe}$ destacar las cartas que dirigió a Toribio Fernández, embajador en Corte romana del rey de Castilla ACA, C, reg. 2967, fol. 23v, Valencia, 9-I-1426. Al canónigo de Valencia, Micer Pere Darnius, procurador en Corte Romana. ACA. C, reg. 2967, fol. 24v, Valencia, 11-1-1426. $\mathrm{Y}$ al doctor fray Lope de Olmedo. ACA, C, reg. 3170, fol. 10, Valencia, 12-XI-1426.

${ }^{67} \mathrm{ACA}, \mathrm{C}$, reg. 2967, fol. 8v, Tarazona, 18-XI-1425. Carta de Doña María al rey de Castilla. 
Por otra parte, Doña María, no se limitó a tratar de procurarle nuevos beneficios, sino que también intervino en numerosas ocasiones para asegurarle la percepción de las rentas anejas a los que ya poseía, siempre que hubo resistencias a entregárselas como consecuencia de su condición de beneficiado absentista. Así, por ejemplo, en 1426 dirigió sendas cartas al obispo y al cabildo de la catedral de Barcelona recriminándoles porque, a pesar de que maestre Francisco de Burgos había obtenido gracia apostólica para poder cobrar los frutos de sus beneficios estando en servicio de la reina, de un tiempo a esta parte no se le estaban pagando los correspondientes a su canonjía en dicha catedral ${ }^{68}$. Por su parte, en 1421 ya se había dirigido al prior del monasterio del Sepulcro de Calatayud para poner fin a la disputa que dicho prior mantenía con maestre Francisco sobre el pago de una pensión de 400 florines que el Papa le había concedido a este último, situándola sobre las rentas del referido priorato. Para facilitar el acuerdo, Doña María propuso al prior que en adelante maestre Francisco sólo percibiese la mitad de la pensión, es decir, 200 florines, pudiéndose quedar con los otros 200 el propio prior, pero con la condición de que al primero no se le pudiese retirar la pensión hasta que fuese proveído de beneficios de otro tanto valor ${ }^{69}$. Y, por fin, de nuevo en 1426 envió una carta a la persona encargada de recaudar los frutos de su arciprestazgo de Tuili en Cerdeña para que inmediatamente enviase el dinero recaudado a Barcelona a poder del procurador de maestre Francisco, Guillem Sacoma, puesto que éste lo necesitaba con urgencia para mantenerse y poder continuar de este modo al servicio de la reina ${ }^{70}$.

Todas estas noticias nos ponen de manifiesto hasta qué punto fue precaria la situación financiera en que se desenvolvió esta reina, y dependió de fuentes externas para asegurar la remuneración de sus servidores, incluso de aquéllos que consideraba más imprescindibles, como era el caso de maestre Francisco de Burgos, no tanto por sus dotes de negociador político y diplomático, que por lo que sabemos apenas tuvo ocasión de ejercitar, sino, sobre todo, porque Doña María tenía depositada una confianza ciega en su capacitación como médico, que le llevó a recurrir a todos los medios a su alcance para evitar que la abandonase y regresase a Castilla. Por ello se preocupó tanto por dotarle de beneficios en la Iglesia, y que pudiese cobrar las rentas adscritas a los mismos, y por ello desplegó una intensa actividad diplomática en la Corte castellana para asegurar que en ésta se le continuaban abonando los salarios y quitaciones que le correspondían como médico del monarca castellano, pese a no poder desempeñar su trabajo como tal por estar permanentemente fuera de dicha Corte.

Ya en 1419 Doña María reconocía que, aunque el doctor maestre Francisco era médico del monarca castellano, residía de continuo en la Corona de Aragón al servicio de su real persona, "porque sabe de nuestra complexión

\footnotetext{
${ }^{68}$ ACA, C, reg. 2967, fol. 58, Valencia, 29-IV-1426.

${ }^{69} \mathrm{ACA}, \mathrm{C}$, reg. 2950, fol. 150v, Tortosa, 18-II-1421.

${ }^{70}$ ACA, C, reg. 2967, fol. 23, Valencia, 9-I-1426.
} 
más que ningún otro físico". Y por ello le había solicitado repetidas veces a su hermano, Juan II de Castilla, que tuviese a bien acrecentarle la quitación que le pagaba, situándola al mismo nivel que las que percibían los demás físicos que servían en su Corte. Tales ruegos al parecer no habían surtido efecto, y por ello maestre Francisco no cesaba de solicitarle que le diese licencia para poder regresar a Castilla, con la esperanza de mejorar su situación económica. Ella se había resistido, no obstante, a concedérsela porque le necesitaba mucho, pero, aprovechando un momento en que se sintió con su salud sensiblemente mejorada, optó finalmente por autorizarle a que se ausentase, aunque sólo por cuarenta días, para que, una vez transcurridos, regresase a su lado. Y así se lo comunicó a su hermano, el rey de Castilla, reiterándole una vez más la solicitud de que le incrementase su sueldo, para que de este modo se pudiese vencer mejor su resistencia a permanecer alejado de la Corte castellana, por miedo a perder dinero ${ }^{71}$. No las tenía todas consigo, sin embargo, la reina de Aragón, y buena prueba de ello es que pocas semanas después escribió a uno de los nobles más influyentes en la Corte castellana en aquellos momentos, Juan Hurtado de Mendoza, mayordomo del rey, informándole que había dado licencia a su físico, maestre Francisco, para viajar a Castilla a despachar un negocio, y solicitándole al mismo tiempo que le hiciese tornar luego a Aragón, para que continuase prestándole sus servicios, de los que no podía prescindir "por él saber más de nuestra complexión y regimiento que otra persona"72. No sabemos cuánto tiempo duró la estancia en la Corte castellana de maestre Francisco en aquella ocasión, pero en cualquier caso nos consta que las dificultades para retenerle a su servicio, por el miedo que él tenía a perder ingresos como consecuencia de su ausencia continuada de la Corte castellana, siguieron estando presentes en los años siguientes. Y por ello Doña María tuvo que continuar realizando enconados esfuerzos en el ámbito diplomático para tratar de conseguir que en la Corte castellana no dejase de pagársele su quitación, pese a su absentismo. Es la misión que encargó al arcediano de Niebla, por carta que le dirigió en noviembre de 1421 , dándole instrucciones para que procurase obtener del monarca castellano provisión en que ordenase a maestre Francisco que no se apartase del servicio de la reina de Aragón sin su licencia, y a los contadores que le continuasen pagando su quitación ${ }^{73}$. Y con este mismo objeto se dirigió en varias ocasiones a Fernán Alfonso de Robles, contador mayor del rey de Castilla, como reconoció en la carta que le envió en noviembre de $1422^{74}$. Pero no sólo ella se movilizó, sino que incluso su marido, el propio rey Alfonso el Magnánimo, llegó a considerar necesario intervenir personalmente en este asunto, dando así prueba de la notable importancia que se le asignaba. Así nos lo demuestra la carta que en febrero de 1422 dirigió a su cuñado y

\footnotetext{
${ }^{71}$ ACA, C, reg. 3109, fol. 47, San Cugat, 22-XII-1419.

${ }^{72}$ ACA, C, reg. 3108, fol. 32v, Tortosa, 30-I-1420.

${ }^{73} \mathrm{ACA}, \mathrm{C}$, reg. 3164 , fol. 125v, Barcelona 15-XI-1421.

${ }^{74} \mathrm{ACA}, \mathrm{C}$, reg. 2962, fol. 7v, Monasterio de Valdoncella, 9-XI-1422
} 
primo, el rey de Castilla, para rogarle que no se le retirasen a maestre Francisco las gracias y quitaciones que percibía en ese reino por estar ausente en Aragón al servicio de su esposa ${ }^{75}$.

\section{OTROS CLÉRIGOS CASTELLANOS AL SERVICIO DE LA REINA MARÍA}

Los personajes de los que hemos tratado hasta ahora destacan por ser los que más huella han dejado en la documentación cancilleresca entre los servidores castellanos de Alfonso el Magnánimo, y, más en particular, de su esposa Doña María, que formaban parte del estamento del clero. Y por ello nos hemos extendido en el análisis de sus figuras, que, como hemos podido comprobar, presentan en cada caso perfiles muy diferentes. Para completar el cuadro, haremos a continuación breve referencia a algunos otros clérigos de origen castellano que estuvieron al servicio de los reyes de Aragón en la primera mitad del siglo XV, para abundar en la demostración de la importancia que llegó a alcanzar este grupo en esa época en la Corte aragonesa.

En concreto cabe destacar que algunos otros individuos que respondían a este mismo perfil fueron empleados ocasionalmente para el desempeño de misiones diplomáticas en la Corte castellana. Es el caso, por ejemplo, del deán de Zamora, Fernando de Luján, a quien en 1447 envió doña María a Castilla a resolver asuntos concernientes a su servicio, de los que, sin embargo, no tenemos apenas detalle ${ }^{76}$. Por su parte, Alfonso $\mathrm{V}$ en una carta que dirigió en 1422 al deán de Salamanca, Mosén Sancho, le agradeció la buena intención que había estado mostrando en la resolución de sus negocios en la Corte del rey de Castilla, al tiempo que le suplicó que continuase así en adelante hasta que los mismos concluyesen con éxito ${ }^{77}$. Pero en este caso no parece que este clérigo permaneciese en Castilla en calidad de embajador del monarca aragonés, sino que simplemente habría asumido la tarea de la defensa de sus intereses por razones de afinidad.

Por lo demás, no sólo miembros del clero secular desempeñaron misiones diplomáticas sino que también lo hicieron, aunque con menos frecuencia, algunos clérigos regulares. Es el caso del prior del monasterio jerónimo de Santa María de Prado de Valladolid, de quien se sirvió en 1450 la reina María para tratar cierto asunto con el relator Fernán Díaz de Toledo, primo del arcediano de Niebla, que fue uno de sus principales hombres de confianza en la Corte castellana, a quien reiteradamente recurrió para que velase en ella por la salvaguarda de sus intereses ${ }^{78}$. Por su parte, en 1453 ,

\footnotetext{
${ }^{75}$ ACA, C, reg. 2672, fol. 135, Nápoles, 28-II-1422.

${ }^{76}$ ACA, C, reg. 3198, fol. 58, Barcelona, 20-II-1447. Salvoconducto para Fernando de Luján.

${ }^{77}$ ACA, C, reg. 3164, fol. 187v, Barcelona, 24-IX-1422.

${ }^{78}$ ACA, C reg. 3202, fol. 93, Perpiñán, 9-II-1450. Carta de la reina María al relator Fernán Díaz de Toledo, en creencia del prior de Santa María de Prado, a quien le envía informado de su intención.
} 
cuando la reina María escribió a Fernando de Riaza solicitándole que le enviase información sobre los graves acontecimientos que estaban ocurriendo en la Corte castellana, que habían culminado en el ajusticiamiento del Condestable Don Álvaro de Luna, dirigió a su vez una carta de idéntico tenor a un tal Miguel Delgado, maestro en Santa Teología, del monasterio de Poblet $^{79}$. No hemos tenido ocasión de profundizar en la reconstrucción del perfil de este personaje, del que desconocemos incluso el origen, aunque es probable que fuese castellano. Pero de la carta que acabamos de mencionar cabe deducir que permaneció un tiempo en la Corte castellana, y que Doña María esperaba de él que la mantuviese puntualmente informada de lo que en ella pasaba.

Un clérigo de origen castellano, por fin, por el que esta reina mostró un constante interés a la hora de buscar beneficios eclesiásticos con los que pudiese mantenerse con holgura, para de este modo premiar sus servicios, fue Diego Gómez de Castro, scolar de su capilla, natural del obispado de Burgos, muy probablemente de la villa de Castrojeriz. A instancias de Doña María, en efecto, se le proveyó en 1419 de una canonjía en la iglesia de Santa María la Mayor de Calatayud, vacante por privación de Mosén Julián de Loba, residente en Peñíscola ${ }^{80}$. Y gracias a la intervención del propio rey Alfonso $\mathrm{V}$, ese mismo año fue proveído del beneficio instituido bajo la invocación de San Jaime en la sede de Valencia, que era de patronato real ${ }^{81}$. Al año siguiente Doña María solicitó al vicario general y al obispo de Tarazona que le proveyesen de alguna canonjía en la catedral de esta ciudad aragonesa ${ }^{82}, \mathrm{y}$, aunque esta solicitud no parece que llegase a ser atendida, sí se consiguió al menos que el referido vicario general le concediese un préstamo en una iglesia de esta diócesis, la de Ibdes, aunque nada más tomar posesión del mismo comenzó a tener problemas con la percepción de sus frutos, que obligaron a la reina a dirigirse al obispo para que los resolviese ${ }^{83}$. También en 1420 Doña María solicitó al obispo de Valencia que concediese a este clérigo de su capilla algún beneficio en su diócesis con el que se pudiese sustentar ${ }^{84}$. Y, por fin, de igual manera se le buscaron beneficios en iglesias castellanas. Éste debía ser el objetivo que perseguía Doña María cuando varias veces a lo largo del año 1422 escribió al arcediano de Niebla, que entonces se encontraba en la Corte castellana, para pedirle que tuviese por recomendado al mencionado Diego

\footnotetext{
${ }^{79} \mathrm{ACA}, \mathrm{C}$, reg. 3214, fol. 1v, Barcelona, 23-VI-1453.

${ }^{80}$ ACA, C, reg. 2609, fol. 86v, Barcelona, 6-III-1419. Carta de Alfonso V al obispo de Tarazona manifestando su deseo de que sea admitido al referido beneficio. Con idéntico objetivo dirigió el rey cartas al cabildo de Santa María la Mayor de Calatayud, y al consejero y alguacil Mosén Gonzalo de Liñán.

${ }^{81}$ ACA, C, reg. 2609, fol. 87v, Barcelona, 8-III-1419. Carta de Alfonso V al baile general de Valencia, rogándole que tenga en especial recomendación a Diego Gómez de Castro, scolar de la capilla de su mujer la reina, para que logre la posesión del referido beneficio, con sus frutos y rentas.

${ }^{82} \mathrm{ACA}, \mathrm{C}$, reg. 3108 , fol. 128v, Calatayud, 21-X-1420.

${ }^{83} \mathrm{ACA}, \mathrm{C}$, reg. 3109, fol. 89v Barcelona, 23-VI-1421.

${ }^{84}$ ACA, C, reg. 2952, fol. 3v, Vilanaroz, 15-IV-1420.
} 
Gómez de Castro, "fiel de su capilla" 85 . Y, en efecto, nos consta que pocos años después ya había obtenido en el arzobispado de Toledo una rectoría llamada de Santa María del Alameda, a raíz de lo cual Doña María se dirigió al arzobispo para solicitarle que le eximiese durante cuatro años de la obligación de residir en dicha iglesia, pues no podía hacerlo por estar a su servicio $^{86}$.

Por contraste con el resto de clérigos de los que hemos tratado en el presente trabajo, entre los servicios prestados por Diego Gómez de Castro a la reina María no nos consta, sin embargo, que se incluyese el desempeño de misiones diplomáticas en la Corona de Castilla. Y dichos servicios tampoco tuvieron nada que ver con la práctica de la medicina, como en el caso de maestre Francisco de Burgos. Es probable, por tanto, que, en este caso si, y como excepción, se circunscribiesen al ámbito estrictamente religioso, o, si se quiere, eclesiástico. En cualquier caso, cualesquiera que fuesen en concreto tales servicios, no cabe duda que la reina Doña María los tuvo en gran estima, a juzgar por el interés demostrado por procurarle tan importante número de beneficios en las iglesias tanto de la Corona de Aragón como de la de Castilla, y por algunas otras mercedes que le efectuó, entre las que cabe mencionar la concesión de dos sinagogas ubicadas en la judería de la ciudad de Calatayud, una llamada de "Las Carneceries", y la otra de "Los Texidores", que obtuvo en el año 1421, tras haber sido confiscadas para incorporarlas al real patrimonio $^{87}$.

\section{CONCLUSIÓN}

Tomando como principal fuente de información los registros de cancillería del Archivo de la Corona de Aragón, preferentemente algunas series que agrupan documentos expedidos por la reina María, hemos tratado en el presente trabajo de profundizar en el estudio del grupo de individuos de origen castellano que sirvieron a los Trastamara en la Corona de Aragón durante el siglo XV. Para ello nos hemos centrado en esta ocasión en aquéllos que pertenecían al estamento del clero, pero que prestaron servicios que no eran específicos de clérigos. Nos ha interesado en particular poner de manifiesto el destacado papel de algunos de ellos en el desempeño de misiones diplomáticas en la Corona de Castilla, que con bastante frecuencia no tuvieron, sin embargo, un contenido eminentemente político, sino que persiguieron de forma preferente la consecución de objetivos de carácter económico, básicamente apuntalar con dineros procedentes de Castilla la maltrecha tesorería de la reina de Aragón. No todos los clérigos de origen

${ }^{85}$ ACA, C, reg. 2962, fol. 9v, Barcelona, 24-XI-1422. Carta de la reina María al arcediano de Niebla, rogánđole que cumpliese lo que le solicitaba en una carta anterior, a la que no había dado respuesta, para que hubiese por recomendado al fiel de su capilla Diego Gómez de Castro.

${ }^{86} \mathrm{ACA}, \mathrm{C}$, reg. 3170, fol. 64, Valencia, 24-V-1427.

${ }^{87} \mathrm{ACA}, \mathrm{C}$, reg. 3119, fol. 123. 
castellano que los monarcas aragoneses, y más en particular la reina María, esposa de Alfonso el Magnánimo, tuvieron en mayor estima entre sus servidores fueron utilizados, sin embargo, para el desempeño de este tipo de misiones, al menos de una forma habitual. Así lo hemos podido comprobar al analizar la interesante figura del maestro Francisco de Burgos, médico y al mismo tiempo bachiller en Santa Teología, a quien esta reina trató por todos los medios a su alcance de retener a su servicio, pero no por su valía como diplomático o como político, sino debido a su capacitación como médico.

Un aspecto de la relación que los monarcas aragoneses mantuvieron con los clérigos de origen castellano que estuvieron a su servicio al que hemos prestado particular atención en el presente trabajo ha sido el de la constante intervención de los primeros para asegurar a estos últimos la obtención del mayor número posible de beneficios eclesiásticos, y la percepción de las rentas correspondientes a los mismos sin tener que cumplir con el requisito de servirlos, residiendo personalmente en las iglesias. Esta forma de proceder, a la que se recurrió de forma sistemática, nos demuestra que estos monarcas dispusieron de recursos propios muy limitados para poner en funcionamiento una ambiciosa política de patronazgo, que les permitiese mantener satisfecha a una numerosa clientela de servidores. Y por ello se vieron forzados a echar mano de la Iglesia, que era entonces una institución muy imbricada con los poderes seculares, que ciertamente la protegían, pero que también se esforzaban por utilizarla al servicio de sus propios intereses.

Fecha de recepción del artículo: mayo de 2010.

Fecha de aceptación y versión final: septiembre de 2010. 